Lukic, R.

\title{
APPLICATION OF ELECTRE METHOD IN PERFORMANCE ANALYSIS OF FOOD RETAILERS IN SERBIA
}

\author{
Radojko Lukic \\ Faculty of Economics, University of Belgrade, Serbia \\ E-mail: radojko.lukic@ekof.bg.ac.rs
}

\begin{abstract}
Various methods of multicriteria optimization have been developed and have recently been widely applied in trade. With this in mind, this paper investigates the performance of food retailers in Serbia based on the ELECTRE method. The goal and purpose of researching the efficiency problems of leading food retailers using the ELECTRE method is to see as realistically as possible their position on the food market in Serbia in order to improve in the future by more efficient control of critical factors and implementation of relevant measures. In addition to the challenges, topicality, significance and complexity, the reasons for researching the given problem in this paper are reflected in that. In addition, by applying the ELECTRE method, more realistic results are obtained in relation to the ratio analysis, especially in combination with other methods of multicriteria analysis (TOPSIS, AHP, ARAS and others). The results of the research show that Delhaize Serbia is the best company in terms of performance. This is the result of Delhaize Serbia's good position in the retail market in Serbia. It applies new business models (private label, sales of organic products, multi-channel sales - stores and electronic). It applies modern concepts of cost management, sales, assets, capital, customers, product categories and profit. In addition to all that, the digitalization of the entire business is at a high level. These and other factors have positively influenced its good positioning on the retail food market in Serbia.
\end{abstract}

Keywords: efficiency, ELECTRE method, factors, retail food, Serbia.

\section{INTRODUCTION}

The issue of measuring the efficiency of food retailers is continuously topical, complex and very important (Berman, 2018; Levy, 2019). For these reasons, it is permanently researched on a global level, by individual countries and by individual food retail companies. At the same time, different, individually or integrated, methods of mathematical programming (multicriteria optimization) are increasingly used (Adriyendi, 2015; Gaur, 2020; Churchman, 1954; Ersoy, 2017; Jain, 2013; Khatrouch, 2017; Memariani, 2009; Milani, 2006; Vural, 2020; Velasquez, 2013; Triantaphyllou, 1998; Wu, 2019; Yeh, 2001). This includes the ELECTRE method. Starting from that, the subject of research in this paper is the assessment of the efficiency of food retailers in Serbia on the basis of the ELECTRE method. The purpose and goal of this is to review the current situation and propose adequate measures to improve the efficiency of food 
retailers in Serbia in the future. This, among other things, reflects the scientific and professional contribution of this paper.

Recently, an increasingly rich literature has been devoted to the analysis of the efficiency of enterprises, including trade, using the ELECTRE method ( Burinskiene, 2014; Wu,, 2019) . In this paper, as far as we know, for the first time in the literature in Serbia and analyzes the efficiency (performance measures) of food retailers in Serbia using the ELECTRE method, which is not the case with other methods (Lukic, 2011, 2019, 2020a, b, c, d, 2021a, b, c, d, e).

The basic hypothesis of the research is that continuous monitoring of the dynamics of efficiency of food retailers in all countries, which means in Serbia, is a prerequisite for its improvement in the future. This provides a basis for timely action in that direction by taking appropriate measures.

The research methodology of the given hypothesis is based on the application of the ELECTRE method. This method can play a significant role in improving the efficiency of retail companies that sell food in Serbia. It makes it easier to see as fully as possible which are the most favourable alternatives (i.e. in our case which are the best food retailers in Serbia in terms of performance) under the given criteria in specific circumstances and limitations.

Empirical data for the needs of research on the issues treated in this paper were obtained from the Business Registers Agency of the Republic of Serbia. In methodological terms, they are "produced" in accordance with relevant international standards and, given that, there are no restrictions on the international comparability of initial data and results.

\section{ELECTRE METHOD}

The main purpose of the ELECTRE (ELimination and Choice Expressing the REality) method is to enable the comparison of alternatives in pairs for each criterion. As part of the successive comparison of the relationship of preferential superiority of alternatives, the agreement index is defined as the amount of evidence supporting the result that "alternative $A j$ is superior to alternative $A k$ " or "more important", while the index of disagreement is opposite to the compatibility index. The ELECTRE method is particularly suitable for solving decision-making problems involving several criteria, with many alternatives being superior (Triantaphyllou, 2018; Khatrouch, 2017; Vural, 2020; Velasquez, 2013). The ELECTRE method takes place through the following steps (Vural, 2020):

Step 1. Creating a decision matrix (A). 
Lukic, $\mathbf{R}$.

The decision matrix (A), in which the criteria (for evaluation) are presented in columns and alternatives in rows, is formulated as follows:

$A_{i j}=\left[\begin{array}{cccc}a_{11} & a_{12} & \ldots & a_{1 n} \\ a_{21} & a_{22} & \ldots & a 2 n \\ \vdots & \vdots & \vdots & \vdots \\ a_{m 1} & a_{m 2} & \cdots & a_{m n}\end{array}\right]$

Step 2. Creating a standard decision matrix (X).

Decision matrix $A$ is transformed by normalization into a standard structure of the decision matrix. Different normalization formulas are used for the criteria of benefits (utility) and costs.

Normalization for benefit criteria is:

$x_{i j}=\frac{a_{i j}}{\sqrt{\sum_{i=1}^{n} a_{i j}^{2}}} i=1, \ldots, m j=1, \ldots, n$.

Normalization for cost criteria is:

$x_{i j}=\frac{\frac{1}{a_{i j}}}{\sqrt{\left(\frac{1}{a_{i j}}\right)^{2}}} i=1, \ldots, m j=1, \ldots, n$.

The standard decision matrix $(X)$ generated with the given formulas is:

$x_{i j}=\left[\begin{array}{cccc}x_{11} & x_{12} & \ldots & x_{1 n} \\ x_{21} & x_{22} & \ldots & x_{2 n} \\ \vdots & \vdots & \vdots & \vdots \\ x_{m 1} & x_{m 2} & \ldots & x_{m n}\end{array}\right]$

Step 3. Creating a weighted (weight) normalized decision matrix (Y).

The standardized matrix is multiplied by the values of $W_{j}$ to obtain a weighted (weight) normalized decision matrix $(Y)$ :

$y_{i j}=\left[\begin{array}{cccc}W_{1} x_{11} & W_{2} x_{12} & \ldots & W_{n} x_{1 n} \\ W_{1} x_{21} & W_{2} x_{22} & \ldots & W_{n} x_{2 n} \\ \vdots & \vdots & \vdots & \vdots \\ W_{1} x_{m 1} & W_{2} x_{m 2} & \cdots & W_{n} x_{m n}\end{array}\right] Y_{i j}=W_{j} x_{i j} i=1, \ldots, m j=1, \ldots, n$. 
$\left(\sum_{i=1}^{n} W_{j}=1\right)$

where Wj weight $j^{\text {th }}$ criterion (Triantaphyllou, 1998).

Step 4 . Determining the set of agreement and disagreement.

The criteria for each pairwise comparison was divided into two separate groups. In the case when alternatives that represent a future solution to the problem are not "the best" according to all criteria, they are then asked to be "better" according to most criteria, and comparisons are made in pairs (Milani, 2006). The characteristics of the ELECTRE method are that each set of consents ( $\left.C_{k l}\right)$ corresponds to a set of disagreements $\left(D_{k l}\right)$, ie that there are as many sets of disagreements as there are sets of consents. The set of elements of disagreement consists of $j$ values that do not belong to the corresponding set of consents. The agreement set $C_{k l}$ of two alternatives $A_{k}$ and $A_{l}$ where $k \geq 1$ and $I$ $\geq 1$, is defined as the set of all criteria so that $A_{k}$ preferred over $A_{l}$ It is displayed as follows:

$C_{k l}=\left\{j, \mid y_{k j} \geq y_{l j}\right\}, j=1,2,3, \ldots, N$.

A complementary set is called a set of disagreements. He is described as (Triantaphyllou, 1998): $D_{k l}=\left\{j, \mid y_{k j}<y_{l j}\right\}, z a j=1,2,3, \ldots, N$.

Step 5 . Creating matrices of agreement $(C)$ and disagreement $(D)$.

The agreement set was used to generate the agreement matrix $(C)$. Matrix $C$ has no value for $k=1$. The elements of this matrix are calculated by the formula: $C_{k l}=\sum_{j \in c_{k l}} W_{j}$.

Here, the agreement index $C_{k l}$ shows how confident (confident), as a result, the comparison is in pairs. Thus, for example, if $C_{12}=\{1,4\}$, then the value of the element $C_{12}$ the matrix $C$ will be $C_{12}=$ $\mathrm{w} 1+\mathrm{w} 4 . \quad$ Matrix $\mathrm{C}$ is

$C=\left[\begin{array}{cccc}- & C_{12} & \cdots & C_{1 n} \\ C_{21} & - & \cdots & C_{2 n} \\ \vdots & \vdots & \vdots & \vdots \\ C_{m 1} & C_{m 2} & \cdots & -\end{array}\right]$

The elements of the nonconformity matrix $(D)$ are calculated using the following formula: 
$d_{k l}=\frac{\sum\left(\left|y_{k j_{j \in D_{k l}}}-y_{l j}\right|\right)}{\sum\left(\left|y_{k j_{j}}-y_{l j}\right|\right)}$.

Matrix $D$ does not take into account the value for $k=1$. Matrix $D$ is

$D=\begin{array}{cccc}- & d_{12} & \cdots & d_{1 n} \\ d_{21} & - & \cdots & d_{2 n} \\ \vdots & \vdots & \vdots & \vdots \\ d_{m 1} & d_{m 2} & \cdots & -\end{array}$

Step 6 . Performing a comparison of excellence.

Once the matrices of agreement and disagreement are calculated, their elements are checked in a certain way, and inappropriate alternatives are eliminated. The dominance of $A_{k}$ alternative over $A_{l}$ alternative is determined on the basis of how large $C_{k l}$ is in the agreement matrix, and small $D_{k l}$ in the disagreement index. The average $C$ and $D$ values $(\bar{C}$ and $\bar{D})$ were calculated. If $C_{k l} \geq \bar{C}$ and $\quad D_{k l} \leq \bar{D}$ then the alternative $A_{k}$ is preferred over the alternative $A_{l}$. The alternatives selected by the ELECTRE method form the core $(K)$. Core $(K)$ is formed according to the following conditions (Milani, 2006):

- The decision point (alternative) in $K$ is not more dominant than the second decision point in $K$ (alternative).

- The decision point (alternative) outside $K$ is behind at least one point in $K$ in the order of preferences.

Step 7 . Calculation of the net index of agreement and disagreement.

If there is more than one alternative in the core, then the choice is determined by calculating the index of net agreement and disagreement. They make it possible to see which alternative is more dominant than the comparable other. If the value of the net index of agreement is the highest, and the index of disagreement is the lowest - an alternative set (with these features) is the solution. The net agreement index $C_{p}^{p} s$ is sorted from higher to lower, and the net index of disagreement $D_{p}^{p} s$ is sorted from lowest to highest. The net index of agreement and disagreement is calculated as follows:

$C_{p}=\sum_{k=1_{k \neq p}}^{m} C_{p k}-\sum_{k=1_{k \neq p}}^{m} C_{k p}$ 
$D_{p}=\sum_{k=1_{k} \neq p}^{m} D_{p k}-\sum_{k=1}^{m} D_{k p}$

The final rank was determined by choosing the highest " $C$ " and the lowest " $D$ " (Milani, 2006).

In this paper, for the purposes of applying the ELECTRE method in the evaluation of the efficiency of food retailers in Serbia, the weighting coefficients are determined on the basis of the AHP (Analytical Hierarchical Process) method. With this in mind, we will briefly review the theoretical characteristics of the AHP method. The Analytical Hierarchical Process (AHP) method includes the following steps (Saaty, 2008):

Step 1: Forming a pair-wise comparison matrix

$$
A=\left[a_{i j}\right]=\left[\begin{array}{cccc}
1 & a_{12} & \cdots & a_{1 n} \\
1 / a_{12} & 1 & \cdots & a_{2 n} \\
\cdots & \cdots \cdots & \cdots & \cdots \\
1 / a_{1 n} & 1 / a_{2 n} & \cdots & 1
\end{array}\right]
$$

Step2: Normalizing the pair-wise comparison matrix

$$
a_{i j}^{*}=\frac{a_{i j}}{\sum_{i=1}^{n} a_{i j}}, i, j=1, \ldots, n
$$

Step 3: Determining the relative importance, i.e. the weight vector

$$
w_{i}=\frac{\sum_{i=1}^{n} a_{i j}^{*}}{n}, i, j=1, \ldots, n
$$

Consistency index $-\mathrm{Cl}$ (consistency index) is a measure of deviation $n$ from $\lambda_{\max }$ and can be represented by the following formula:

$$
C I=\frac{\lambda_{\max }-n}{n}
$$

If $\mathrm{Cl}<0.1$, the estimated values of the coefficients $a_{i j}$ are consistent, and the deviation $\lambda_{\max }$ from $n$ is negligible. This means, in other words, that the AHP method accepts an inconsistency of less than $10 \%$. Using the consistency index, the consistency ratio $\mathrm{CR}=\mathrm{Cl} / \mathrm{RI}$ can be calculated, where $\mathrm{Rl}$ is a random index. 


\section{Lukic, $\mathbf{R}$.}

\section{MEASURING THE PERFORMANCE OF FOOD RETAILERS IN SERBIA BASED ON THE \\ ELECTRE METHOD}

During the measurement of performance of retailers food in Serbia using ELECTRE method as well as the criteria have been taken: C1 - gross margin on inventories, C2 - gross margin on sales, C3 inventory turnover ratio, C4 - company size and C5 - capital intensity. Alternatives are chosen food retailers in Serbia. Table 1 shows the initial data in the form of ratio numbers for measuring the performance of food retailers in Serbia based on the ELECTRE I method for 2019. The study included leading food retailers in Serbia.

TABLE 1. INITIAL DATA FOR MEASURING THE PERFORMANCE OF FOOD RETAILERS IN SERBIA

\begin{tabular}{|c|c|c|c|c|c|}
\hline & $\begin{array}{l}\text { Gross margin } \\
\text { on inventories } \\
\text { (Gross margin } \\
\text { / Inventories } \\
(\%)\end{array}$ & $\begin{array}{l}\text { Gross margin } \\
\text { on sales (Gross } \\
\text { margin / } \\
\text { Sales) (\%) }\end{array}$ & $\begin{array}{l}\text { Inventory turnover } \\
\text { ratio (Sales / } \\
\text { Supplies) }\end{array}$ & $\begin{array}{l}\text { Company size } \\
\text { (Log10 sale) }\end{array}$ & $\begin{array}{l}\text { Capital } \\
\text { intensity (Fixed } \\
\text { assets / } \\
\text { Assets) }\end{array}$ \\
\hline Delhaize Serbia & 402.61 & 29.71 & 13.55 & 5.02 & 0.51 \\
\hline Mercator-S & 214.31 & 23.38 & 9.16 & 4.89 & 0.69 \\
\hline Univerexport & 224.93 & 23.37 & 9.62 & 4.3 & 0.69 \\
\hline DIS & 102.32 & 10.22 & 10.01 & 4.3 & 0.72 \\
\hline Delta Agrar & 13.94 & 5.16 & 2.7 & 4.31 & 0.58 \\
\hline Gomex & 168.08 & 17.85 & 9.41 & 4.13 & 0.48 \\
\hline Lidl Serbia & 219.88 & 21.59 & 10.18 & 4.57 & 0.76 \\
\hline Matijević DOO & 15.2 & 9.54 & 1.59 & 3.71 & 0.68 \\
\hline \multicolumn{6}{|l|}{ Statistics } \\
\hline Mean & 170.1588 & 17.6025 & 8.2775 & 4.4038 & .6388 \\
\hline $\begin{array}{l}\text { Std. Error of } \\
\text { Mean }\end{array}$ & 45.21337 & 2.99856 & 1.42751 & .14823 & .03623 \\
\hline Median & 191.1950 & 19.7200 & 9.5150 & 4.3050 & .6850 \\
\hline Std. Deviation & 127.88272 & 8.48122 & 4.03759 & .41925 & .10246 \\
\hline Skewness & .463 & -.197 & -.895 & -.010 & -.652 \\
\hline $\begin{array}{l}\text { Std. Error of } \\
\text { Skewness }\end{array}$ & .752 & .752 & .752 & .752 & .752 \\
\hline Kurtosis & .397 & -1.247 & -.039 & -.034 & -1.172 \\
\hline $\begin{array}{l}\text { Std. Error of } \\
\text { Kurtosis }\end{array}$ & 1.481 & 1.481 & 1.481 & 1.481 & 1.481 \\
\hline Minimum & 13.94 & 5.16 & 1.59 & 3.71 & .48 \\
\hline Maximum & 402.61 & 29.71 & 13.55 & 5.02 & .76 \\
\hline Mean & 170.1588 & 17.6025 & 8.2775 & 4.4038 & .6388 \\
\hline \multicolumn{6}{|l|}{ Test statistics ${ }^{a}$} \\
\hline $\mathrm{N}$ & 8 & & & & \\
\hline Chi-Square & 30.800 & & & & \\
\hline df & 4 & & & & \\
\hline Asymp. Sig. & .000 & & & & \\
\hline a. Friedman Test & & & & & \\
\hline
\end{tabular}


There is a significant difference between the observed variables at the level of statistical significance (Asymp. Sig. .000<.05), so that the null hypothesis that there are no differences between them is rejected. According to the ratio analysis, the food retailer Delhaize Serbia is the best in all performance indicators in relation to the observed food retailers in Serbia. This is, among other things, the result of a good knowledge of the specifics of doing business in the retail food market in Serbia.

TABLE 2. CORRELATIONS

\begin{tabular}{|c|c|c|c|c|c|c|}
\hline \multicolumn{7}{|c|}{ Correlations } \\
\hline & & 1 & 2 & 3 & 4 & 5 \\
\hline 1 Gross & Pearson Correlation & 1 & $.958^{* *}$ & $.891^{* *}$ & $.792^{\star}$ & -.231 \\
\hline \multirow{2}{*}{$\begin{array}{l}\text { margin on } \\
\text { inventorie }\end{array}$} & Sig. (2-tailed) & & .000 & .003 & .019 & .581 \\
\hline & $\mathrm{N}$ & 8 & 8 & 8 & 8 & 8 \\
\hline \multirow{3}{*}{$\begin{array}{lr}2 & \text { Gross } \\
\text { margin } & \text { on } \\
\text { sales } & \\
\end{array}$} & Pearson Correlation & $.958^{* *}$ & 1 & $.814^{*}$ & $.715^{*}$ & -.119 \\
\hline & Sig. (2-tailed) & .000 & & .014 & .046 & .779 \\
\hline & $\mathrm{N}$ & 8 & 8 & 8 & 8 & 8 \\
\hline \multirow{3}{*}{$\begin{array}{l}3 \text { Inventory } \\
\text { turnover ratio }\end{array}$} & Pearson Correlation & $.891^{* *}$ & $.814^{*}$ & 1 & $.720^{\circ}$ & -.111 \\
\hline & Sig. (2-tailed) & .003 & .014 & & .044 & .794 \\
\hline & $\mathrm{N}$ & 8 & 8 & 8 & 8 & 8 \\
\hline \multirow{3}{*}{$\begin{array}{l}4 \text { Company } \\
\text { size }\end{array}$} & Pearson Correlation & $.792^{*}$ & $.715^{*}$ & $.720^{*}$ & 1 & -.092 \\
\hline & Sig. (2-tailed) & .019 & .046 & .044 & & .828 \\
\hline & $\mathrm{N}$ & 8 & 8 & 8 & 8 & 8 \\
\hline \multirow{3}{*}{$\begin{array}{l}5 \quad \text { Capital } \\
\text { intensity C }\end{array}$} & Pearson Correlation & -.231 & -.119 & -.111 & -.092 & 1 \\
\hline & Sig. (2-tailed) & .581 & .779 & .794 & .828 & \\
\hline & $\mathrm{N}$ & 8 & 8 & 8 & 8 & 8 \\
\hline \multicolumn{7}{|c|}{${ }^{* *}$. Correlation is significant at the 0.01 level (2-tailed). } \\
\hline
\end{tabular}

Note: Author's calculation

There is a strong correlation between the observed variables at the level of statistical significance, except for capital intensity. The weighting coefficients of the selected criteria were determined using the AHP method. They are shown in Table 3 and Figure 1.

TABLE 3. AHP METHOD: PRIORITY RESULTS

\section{Resulting Priorities}

Priorities

These are the resulting weights for the criteria based on your pairwise comparisons:

\begin{tabular}{|l|l|l|l|l|l|}
\hline \multicolumn{2}{|l|}{ Chat } & Priority & Rank & $(+)$ & $(-)$ \\
\hline 1 & Gross margin on inventories & $50.1 \%$ & 1 & $13.0 \%$ & $13.0 \%$ \\
\hline 2 & Gross margin on sales & $21.6 \%$ & 2 & $6.2 \%$ & $6.2 \%$ \\
\hline 3 & Inventory turnover ratio & $16.4 \%$ & 3 & $5.2 \%$ & $5.2 \%$ \\
\hline 4 & Company size & $7.6 \%$ & 4 & $1.7 \%$ & $1.7 \%$ \\
\hline 5 & Capital intensity & $4.4 \%$ & 5 & $1.0 \%$ & $1.0 \%$ \\
\hline
\end{tabular}


Lukic, $\mathbf{R}$.

APPLICATION OF ELECTRE METHOD IN PERFORMANCE ANALYSIS OF FOOD RETAILERS IN SERBIA

\section{Decision Matrix}

The resulting weights are based on the principal eigenvector of the decision matrix:

\begin{tabular}{|l|l|l|l|l|l|}
\hline 1 & 1 & 2 & 3 & 4 & 5 \\
\hline 2 & 1 & 3.00 & 4.00 & 5.00 & 9.00 \\
\hline 3 & 0.33 & 1 & 2.00 & 3.00 & 4.00 \\
\hline 4 & 0.25 & 0.50 & 1 & 3.00 & 5.00 \\
\hline 5 & 0.20 & 0.33 & 0.33 & 1 & 2.00 \\
\hline $\begin{array}{l}\text { Number of comparisons }=10 \text { Consistency Ratio CR }=3.2 \% \\
\text { Principal Eigen value }=5.143 \text { Eigenvector solution: } 4 \text { iterations, delta = 6.4E -8 }\end{array}$ & 0.11 & 0.25 & 0.20 & 0.50 & 1 \\
\hline
\end{tabular}

Note: The author's calculating using the program AHP online calculator

Source: Author's calculation

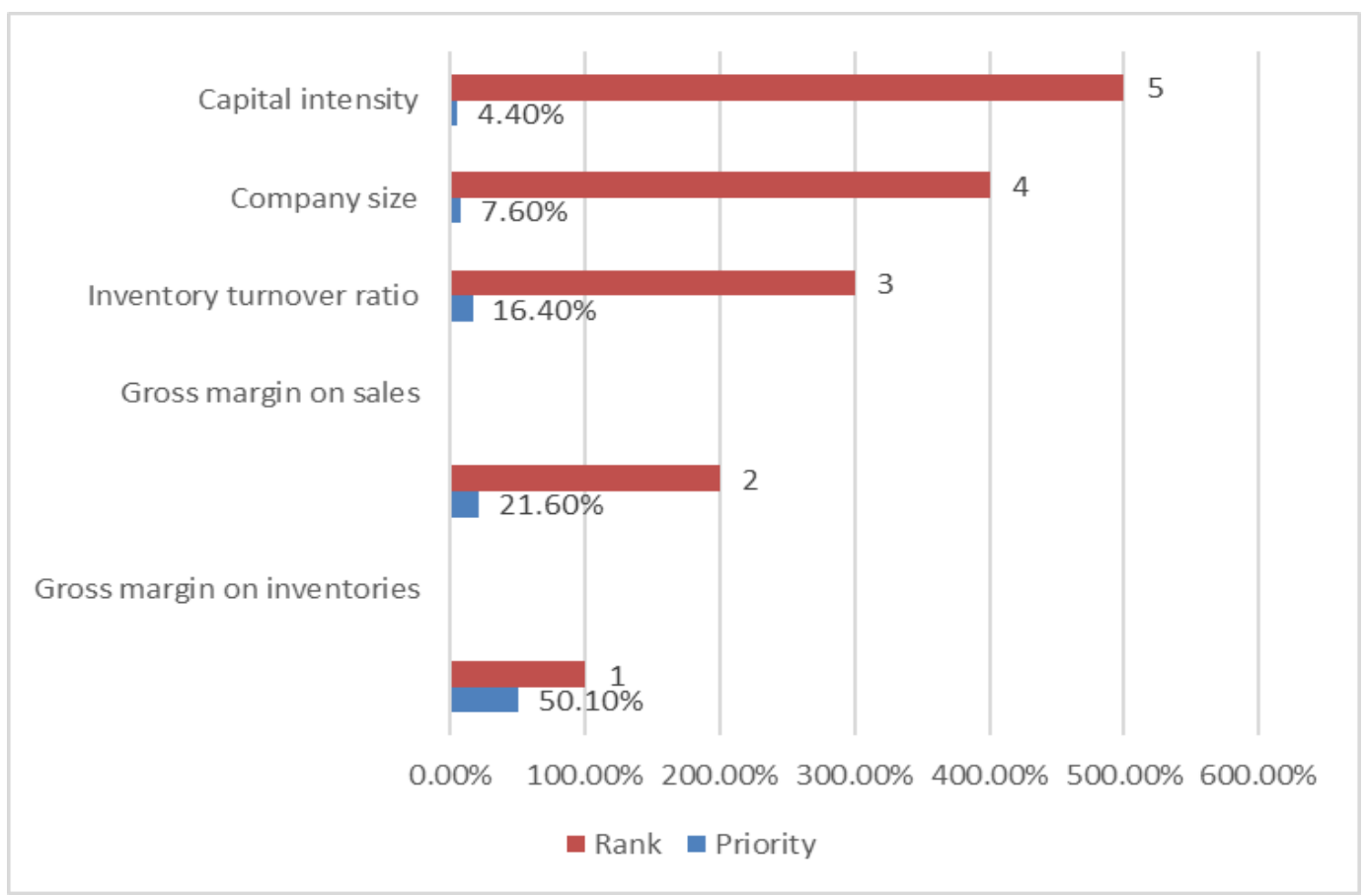

FIGURE 1. WEIGHT COEFFICIENTS OF CRITERIA

Source: Author's picture

The importance of individual criteria in the order is, therefore, according to AHP method as follows: gross margin on inventories, gross margins on sales, inventory turnover ratio, company size and capital intensity. Effective control of these factors can achieve the target performance of food retailers in Serbia. 
Lukic, $\mathbf{R}$.

APPLICATION OF ELECTRE METHOD IN PERFORMANCE ANALYSIS OF FOOD RETAILERS IN SERBIA

The obtained results of the research of the efficiency of the leading food retailers in Serbia using the ELECTRE method are presented in the tables below, as well as graphically. The order of the tables (4 13) follows the phases of calculation using the ELECTRE method. The calculation was performed using the software program ELECTRESoftware-Excel.

Table 4 shows the initial decision matrix.

TABLE 4. INITIAL DECISION MATRIX

\begin{tabular}{|c|c|c|c|c|c|c|}
\hline \multicolumn{7}{|c|}{ Initial Decision Matrix } \\
\hline Weights of Criteria & 0.501 & & 0.216 & 0.164 & 0.076 & 0.044 \\
\hline \multirow[t]{2}{*}{ Kind of Criteria } & \multicolumn{2}{|l|}{1} & 1 & 1 & 1 & 1 \\
\hline & \multicolumn{2}{|l|}{ C1 } & C2 & C3 & $\mathrm{C} 4$ & C5 \\
\hline A1 & \multicolumn{2}{|l|}{402.61} & 29.71 & 13.55 & 5.02 & 0.51 \\
\hline A2 & 214.31 & \multicolumn{2}{|l|}{23.38} & 9.16 & 4.89 & 0.69 \\
\hline A3 & 224.93 & & 23.37 & 9.62 & 4.3 & 0.69 \\
\hline A4 & 102.32 & \multicolumn{2}{|l|}{10.22} & 10.01 & 4.3 & 0.72 \\
\hline A5 & 13.94 & \multicolumn{2}{|l|}{5.16} & 2.7 & 4.31 & 0.58 \\
\hline A6 & 168.08 & \multicolumn{2}{|l|}{17.85} & 9.41 & 4.13 & 0.48 \\
\hline A7 & \multicolumn{2}{|l|}{219.88} & & 10.18 & 4.57 & 0.76 \\
\hline A8 & 15.2 & 9.54 & & 1.59 & 3.71 & 0.68 \\
\hline SUM OF SQUARES & & 346109.9 & 2982.3 & 662.251 & 156.3745 & 3.3375 \\
\hline SQRT & & 588.3111 & 54.6105 & 25.7342 & 12.50498 & 1.826883 \\
\hline
\end{tabular}

Table 5 shows the normalized decision matrix.

TABLE 5. NORMALIZED DECISION MATRIX

\begin{tabular}{|l|l|l|l|l|l|}
\hline $\begin{array}{l}\text { Normalized Decision } \\
\text { Matrix }\end{array}$ & & & & & \\
\hline Weights of Criteria & 0.501 & 0.216 & 0.164 & 0.076 & 0.044 \\
\hline Kind of Criteria & 1 & 1 & 1 & 1 & 1 \\
\hline & C1 & C2 & C3 & C4 & C5 \\
\hline A1 & 0.6843 & 0.5440 & 0.5265 & 0.4014 & 0.2792 \\
\hline A2 & 0.3643 & 0.4281 & 0.3559 & 0.3910 & 0.3777 \\
\hline A3 & 0.3823 & 0.4279 & 0.3738 & 0.3439 & 0.3777 \\
\hline A4 & 0.1739 & 0.1871 & 0.3890 & 0.3439 & 0.3941 \\
\hline A5 & 0.0237 & 0.0945 & 0.1049 & 0.3447 & 0.3175 \\
\hline A6 & 0.2857 & 0.3269 & 0.3657 & 0.3303 & 0.2627 \\
\hline A7 & 0.3737 & 0.3953 & 0.3956 & 0.3655 & 0.4160 \\
\hline A8 & 0.0258 & 0.1747 & 0.0618 & 0.2967 & 0.3722 \\
\hline
\end{tabular}

Source: Author's calculation 
Lukic, $\mathbf{R}$.

APPLICATION OF ELECTRE METHOD IN PERFORMANCE ANALYSIS OF FOOD RETAILERS IN SERBIA

Table 6 shows the weighted normalized decision matrix.

TABLE 6. WEIGHTED NORMALIZED DECISION MATRIX

\begin{tabular}{|l|l|l|l|l|l|}
\hline $\begin{array}{l}\text { Weighted Normalized } \\
\text { Decision Matrix }\end{array}$ & & & & & \\
\hline Weights of Criteria & 0.501 & 0.216 & 0.164 & 0.076 & 0.044 \\
\hline Kind of Criteria & 1 & 1 & 1 & 1 & 1 \\
\hline & C1 & C2 & C3 & C4 & C5 \\
\hline A1 & 0.3429 & 0.1175 & 0.0864 & 0.0305 & 0.0123 \\
\hline A2 & 0.1825 & 0.0925 & 0.0584 & 0.0297 & 0.0166 \\
\hline A3 & 0.1915 & 0.0924 & 0.0613 & 0.0261 & 0.0166 \\
\hline A4 & 0.0871 & 0.0404 & 0.0638 & 0.0261 & 0.0173 \\
\hline A5 & 0.0119 & 0.0204 & 0.0172 & 0.0262 & 0.0140 \\
\hline A6 & 0.1431 & 0.0706 & 0.0600 & 0.0251 & 0.0116 \\
\hline A7 & 0.1872 & 0.0854 & 0.0649 & 0.0278 & 0.0183 \\
\hline A8 & 0.0129 & 0.0377 & 0.0101 & 0.0225 & 0.0164 \\
\hline
\end{tabular}

Table 7 shows the determine the concordance and discordance

TABLE 7. DETERMINE THE CONCORDANCE AND DISCORDANCE

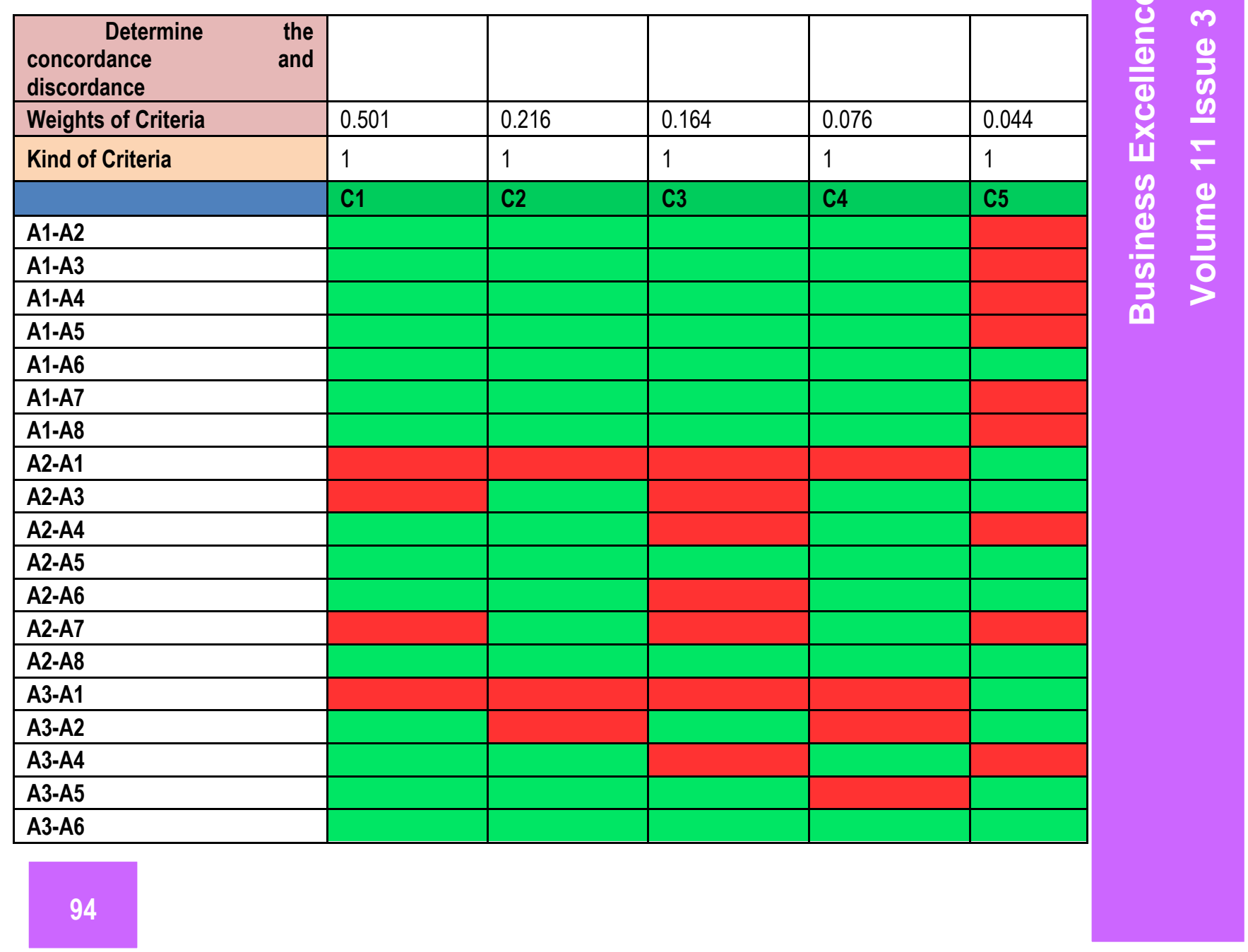


Lukic, $\mathbf{R}$.

APPLICATION OF ELECTRE METHOD IN PERFORMANCE ANALYSIS OF FOOD RETAILERS IN SERBIA

\begin{tabular}{|l|l|l|l|l|l|}
\hline A3-A7 & & & & \\
\hline A3-A8 & & & & & \\
\hline A4-A1 & & & & & \\
\hline A4-A2 & & & & & \\
\hline A4-A3 & & & & & \\
\hline A4-A5 & & & & & \\
\hline A4-A6 & & & & & \\
\hline A4-A7 & & & & & \\
\hline A4-A8 & & & & & \\
\hline A5-A1 & & & & & \\
\hline A5-A2 & & & & & \\
\hline A5-A3 & & & & & \\
\hline A5-A4 & & & & & \\
\hline A5-A6 & & & & & \\
\hline A5-A7 & & & & & \\
\hline A5-A8 & & & & & \\
\hline A6-A1 & & & & & \\
\hline A6-A2 & & & & & \\
\hline A6-A3 & & & & & \\
\hline A6-A4 & & & & & \\
\hline A6-A5 & & & & & \\
\hline A6-A7 & & & & & \\
\hline A6-A8 & & & & & \\
\hline A7-A1 & & & & & \\
\hline A7-A2 & & & & & \\
\hline A7-A3 & & & & & \\
\hline A7-A4 & & & & \\
\hline A7-A5 & & & & \\
\hline A7-A6 & & & & \\
\hline A7-A8 & & & & \\
\hline A8-A1 & & & & \\
\hline A8-A2 & & & & \\
\hline A8-A3 & & & & \\
\hline A8-A4 & & & & \\
\hline A8-A5 & & & & \\
\hline A8-A6 & & & & \\
\hline A8-A7 & & & & \\
\hline Notice that the green cells contain the concordance set and the red cells contain the discordance set. & \\
\hline
\end{tabular}

Source: Author's calculation

Table 8 shows the concordance matrix.

TABLE 8. CONCORDANCE MATRIX

\begin{tabular}{|l|l|l|l|l|l|l|l|l|}
\hline $\begin{array}{l}\text { Concordance } \\
\text { Matrix }\end{array}$ & & & & & & & & \\
\hline & A1 & A2 & A3 & A4 & A5 & A6 & A7 & A8 \\
\hline A1 & & 0.9570 & 0.9570 & 0.9570 & 0.9570 & 1.0010 & 0.9570 & 0.9570 \\
\hline
\end{tabular}


Lukic, $\mathbf{R}$.

APPLICATION OF ELECTRE METHOD IN PERFORMANCE ANALYSIS OF FOOD RETAILERS IN SERBIA

\begin{tabular}{|l|l|l|l|l|l|l|l|l|}
\hline A2 & 0.0440 & & 0.3360 & 0.7930 & 1.0010 & 0.8370 & 0.2920 & 1.0010 \\
\hline A3 & 0.0440 & 0.7090 & & 0.7930 & 0.9250 & 1.0010 & 0.7170 & 1.0010 \\
\hline A4 & 0.0440 & 0.2080 & 0.2840 & & 0.9250 & 0.2840 & 0.0000 & 1.0010 \\
\hline A5 & 0.0440 & 0.0000 & 0.0760 & 0.0760 & & 0.1200 & 0.0000 & 0.2400 \\
\hline A6 & 0.0000 & 0.1640 & 0.0000 & 0.7170 & 0.8810 & & 0.0000 & 0.9570 \\
\hline A7 & 0.0440 & 0.7090 & 0.2840 & 1.0010 & 1.0010 & 1.0010 & & 1.0010 \\
\hline A8 & 0.0440 & 0.0000 & 0.0000 & 0.0000 & 0.7610 & 0.0440 & 0.0000 & \\
\hline
\end{tabular}

TOTAL AMOUNT

\subsection{0}

Source: Author's calculation

Table 9 shows the discordance matrix.

TABLE 9. DISCORDANCE MATRIX

\begin{tabular}{|l|l|l|l|l|l|l|l|l|}
\hline $\begin{array}{l}\text { Discordance } \\
\text { Matrix }\end{array}$ & & & & & & & & \\
\hline & A1 & A2 & A3 & A4 & A5 & A6 & A7 & A8 \\
\hline A1 & & 0.0270 & 0.0287 & 0.0198 & 0.0051 & 0.0000 & 0.0387 & 0.0124 \\
\hline A2 & 1.0000 & & 1.0000 & 0.0568 & 0.0000 & 0.0405 & 0.9181 & 0.0000 \\
\hline A3 & 1.0000 & 0.3965 & & 0.0238 & 0.0003 & 0.0000 & 0.5069 & 0.0000 \\
\hline A4 & 1.0000 & 1.0000 & 1.0000 & & 0.0008 & 1.0000 & 1.0000 & 0.0000 \\
\hline A5 & 1.0000 & 1.0000 & 1.0000 & 1.0000 & & 1.0000 & 1.0000 & 1.0000 \\
\hline A6 & 1.0000 & 1.0000 & 1.0000 & 0.1032 & 0.0183 & & 1.0000 & 0.0370 \\
\hline A7 & 1.0000 & 1.0000 & 1.0000 & 0.0000 & 0.0000 & 0.0000 & & 0.0000 \\
\hline A8 & 1.0000 & 1.0000 & 1.0000 & 1.0000 & 0.4083 & 1.0000 & 1.0000 & \\
\hline
\end{tabular}

TOTAL

AMOUNT 
Threshold

Value

\subsection{2}

Source: Author's calculation

Table 10 shows the concordance dominance matrix.

TABLE 10. CONCORDANCE DOMINANCE MATRIX

\begin{tabular}{|l|l|l|l|l|l|l|l|l|}
\hline $\begin{array}{l}\text { Concordance } \\
\text { Dominance Matrix }\end{array}$ & & & & & & & & \\
\hline & A1 & A2 & A3 & A4 & A5 & A6 & A7 & A8 \\
\hline A1 & & 1 & 1 & 1 & 1 & 1 & 1 & 1 \\
\hline A2 & 0 & & 0 & 1 & 1 & 1 & 0 & 1 \\
\hline A3 & 0 & 1 & & 1 & 1 & 1 & 1 & 1 \\
\hline A4 & 0 & 0 & 0 & & 1 & 0 & 0 & 1 \\
\hline A5 & 0 & 0 & 0 & 0 & & 0 & 0 & 0 \\
\hline A6 & 0 & 0 & 0 & 1 & 1 & & 0 & 1 \\
\hline A7 & 0 & 1 & 0 & 1 & 1 & 1 & & 1 \\
\hline A8 & 0 & 0 & 0 & 0 & 1 & 0 & 0 & \\
\hline
\end{tabular}

Source: Author's calculation

Table 11 shows the matrix of disagreement dominance.

TABLE 11. DISAGREEMENT DOMINANCE MATRIX

\begin{tabular}{|l|l|l|l|l|l|l|l|l|}
\hline $\begin{array}{l}\text { Discordance } \\
\text { Dominance } \\
\text { Matrix }\end{array}$ & & & & & & & & \\
\hline & A1 & A2 & A3 & A4 & A5 & A6 & A7 & A8 \\
\hline A1 & & 1 & 1 & 1 & 1 & 1 & 1 & 1 \\
\hline A2 & 0 & & 0 & 1 & 1 & 1 & 0 & 1 \\
\hline A3 & 0 & 1 & & 1 & 1 & 1 & 1 & 1 \\
\hline A4 & 0 & 0 & 0 & & 1 & 0 & 0 & 1 \\
\hline A5 & 0 & 0 & 0 & 0 & & 0 & 0 & 0 \\
\hline A6 & 0 & 0 & 0 & 1 & 1 & & 0 & 1 \\
\hline A7 & 0 & 0 & 0 & 1 & 1 & 1 & & 1 \\
\hline A8 & 0 & 0 & 0 & 0 & 1 & 0 & 0 & \\
\hline
\end{tabular}

Source: Author's calculation 
Lukic, $\mathbf{R}$.

APPLICATION OF ELECTRE METHOD IN PERFORMANCE ANALYSIS OF FOOD RETAILERS IN SERBIA

Table 12 shows the dominance aggregation matrix.

TABLE 12. AGGREGATE DOMINANCE MATRIX

\begin{tabular}{|l|l|l|l|l|l|l|l|l|l|}
\hline $\begin{array}{l}\text { Aggregate } \\
\text { Dominance } \\
\text { Matrix }\end{array}$ & & & & & & & & & \\
\hline & A1 & A2 & A3 & A4 & A5 & A6 & A7 & A8 & SUM \\
\hline A1 & & 1 & 1 & 1 & 1 & 1 & 1 & 1 & 7 \\
\hline A2 & 0 & & 0 & 1 & 1 & 1 & 0 & 1 & 4 \\
\hline A3 & 0 & 1 & & 1 & 1 & 1 & 1 & 1 & 6 \\
\hline A4 & 0 & 0 & 0 & & 1 & 0 & 0 & 1 & 2 \\
\hline A5 & 0 & 0 & 0 & 0 & & 0 & 0 & 0 & 0 \\
\hline A6 & 0 & 0 & 0 & 1 & 1 & & 0 & 1 & 3 \\
\hline A7 & 0 & 0 & 0 & 1 & 1 & 1 & & 1 & 4 \\
\hline A8 & 0 & 0 & 0 & 0 & 1 & 0 & 0 & & 1 \\
\hline SUM & 0 & 2 & 1 & 5 & 7 & 4 & 2 & 6 & \\
\hline
\end{tabular}

Table 13 and Figure 2 show the ranking of alternatives.

TABLE 13. RANKING OF ALTERNATIVES

\begin{tabular}{|c|c|c|c|c|}
\hline & \multicolumn{4}{|l|}{ Ranking } \\
\hline & Alternatives & $\begin{array}{l}\text { Sum of } \\
\text { Rows }\end{array}$ & $\begin{array}{l}\text { Sum } \\
\text { Columns }\end{array}$ & Final Solution \\
\hline Delhaize Serbia & A1 & 7 & 0 & 7 \\
\hline Mercator-S & A2 & 4 & 2 & 2 \\
\hline Univerexport & A3 & 6 & 1 & 5 \\
\hline DIS & A4 & 2 & 5 & -3 \\
\hline Delta Agrar & A5 & 0 & 7 & -7 \\
\hline Gomex & A6 & 3 & 4 & -1 \\
\hline Lidl Serbia & A7 & 4 & 2 & 2 \\
\hline Matijević DOO & A8 & 1 & 6 & -5 \\
\hline
\end{tabular}

Source: Author's calculation 


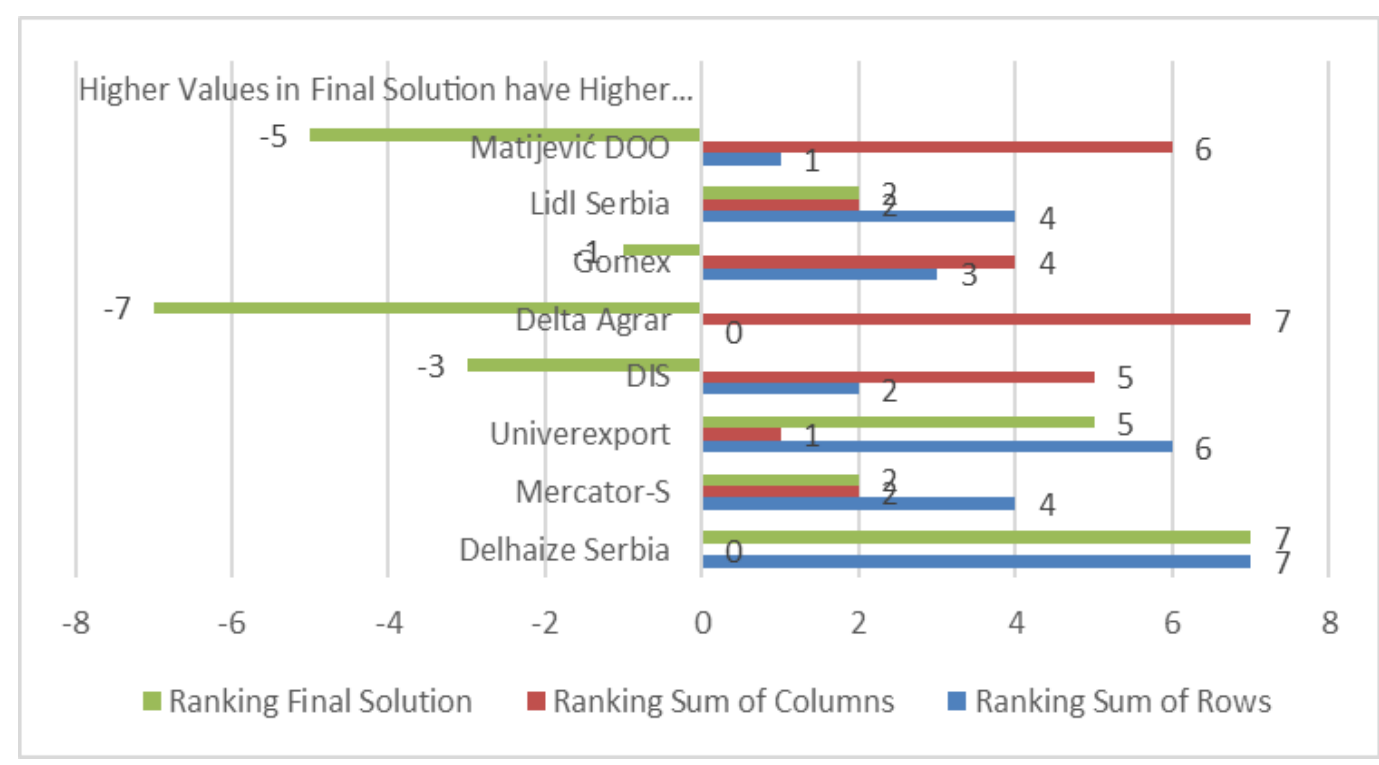

FIGURE 1. RANKING OF ALTERNATIVES

Source: Author's picture

Based on the obtained results of the research on the efficiency of food retailers in Serbia using the ELECTRE I method, it can be stated that Delhaize Serbia is in the first place in terms of performance. They follow in order: Univerexport, Mercator-S, LIDL Serbia (shares the same place with Mercator-S), Gomex, DIS, Matijević DOO and Delta Agrar.Delhaize Serbia has been operating in Serbia for a long time, and is well acquainted with consumer requirements and the business environment. This had a positive effect on its good positioning on the food retail market in Serbia. Thanks to its specific business strategy, Univerexport is well positioned on the retail market in Serbia. In order to improve the performance of food retailers in Serbia, it is necessary to manage revenues, costs and stocks as efficiently as possible. Likewise, firm size and capital intensity need to be optimized.

In order to see the most realistic efficiency of food retailers in Serbia, it is necessary, in addition to the ratio analysis, statistical analysis, to use the ELECTRE method. And especially in combination with other methods of multicriteria analysis (TOPSIS, AHP, VASPAS and others), as well as DEA models.

\section{CONCLUSION}

Based on the conducted empirical research in this paper, we can conclude the following:

(1) According to the ratio analysis, according to all analyzed performance indicators, the retailer Delhaize Serbia is better than the observed food retailers in Serbia. This is a consequence, among other things, of a good knowledge of the specifics of the retail food market in Serbia in terms of customer requirements. 
(2) According to the obtained analysis results of the efficiency of food retailers in Serbia using the ELECTRE I method, it can be concluded that Delhaize Serbia is in the first place in terms of performance. They follow in order: Univerexport, Mercator-S, LIDL Serbia (shares the same place with Mercator-S), Gomex, DIS, Matijević DOO and Delta Agrar. Delhaize Serbia has been operating in Serbia for a long time, and is well acquainted with consumer requirements and the business environment. This had a positive effect on its good positioning on the food retail market in Serbia. Thanks to its specific business strategy, Univerexport is positioned in the retail food market in Serbia.

(3) In order to improve the performance of food retailers in Serbia, it is necessary to manage revenues, costs and stocks as efficiently as possible. Likewise, firm size and capital intensity need to be optimized.

(4) Research on the example of food retailers in Serbia shows that the application of the Elektra method provides a realistic evaluation of the efficiency of food retailers as a starting point for improvement in the future by more efficient control of critical factors and application of relevant measures. For these reasons, generally speaking, its application in the analysis of the efficiency of food retailers is recommended. In addition, other methods of multi-criteria analysis should be used, such as VASPAS, ARAS, SAW and others.

\section{REFERENCES}

Adriyendi, S. (2015). Multi attribute decision making using simple additive weighting and weighted product in food choice. Information Engineering and Electronic Business , 6, 8-14.

Berman, B. R., Evans, J. R., Chatterjee, P. M. (2018). Retail Management: A Strategic Approach. $13^{\text {th }}$ Edition, Perason.

Burinskiene, A., \& Daskevic, D. (2014). Consumer demand: Online or retail stores. Economics \& Management , 19 (2), 172-186.

Gaur, L., Agarwal, V., Anshu, K. (2020). Fuzzy DEMATEL Approach to Identify the Factors Influencing Efficiency of Indian Retail Websites. In: Kapur P., Singh O., Khatri S., Verma A. (eds) Strategic System Assurance and Business Analytics. Asset Analytics (Performance and Safety Management). Springer, Singapore. https://doi.org/10.1007/978-981-15-3647-2 6 .

Churchman, C.W. and Ackoff, R. L. (1954). An approximate measure of value. Journal of Operations Research Society of America , 2 (1), 172-187.

Ersoy, N. (2017). Performance measurement in retail industry by using a multi-criteria decision making methods. Ege Academic Review , 17 (4), 539-551. https://doi.org/10.21121/eab.2017431302

Jain, V. and Raj, T. (2013). Evaluation of flexibility in FMS using SAW and WPM. DecisionScience Letters , 2 (4), 223-230.

Khatrouch, I., Kermad, L., el Mhamedi, A., \& Boujelbene, Y. (2017). A hybrid AHP-ELECTRE I multicriteria model for performance assessment and team selection. Organizational productivity and performance measurements using predictive modeling and analytics. IGI Global, 115-127.

Levy, M., Weitz, B., Grewal, D. (2019). Retailing Management. 10 $0^{\text {th }}$ Edition, Mc Graw Hill.

Lukić, R. (2011). Evaluacija poslovnih performansi u maloprodaji. Beograd: Ekonomski fakultet. 
Lukic, R. and Hadrovic Zekic, B. (2019). Evaluation of efficiency of trade companies in Serbia using the DEA approach. Proceedings of the 19th International Scientific Conference BUSINESS LOGISTICS IN MODERN MANAGEMENT October 10-11, Osijek, Croatia, Josip Juraj Strossmayer University of Osijek, Faculty of Economics in Osijek, 145-165.

Lukic, R, Hadrovic Zekic, B. and Crnjac Milic, D. (2020a). Financial performance evaluation of trading companies in Serbia using the integrated Fuzzy AHP - TOPSIS Approach. 9th INTERNATIONAL SCIENTIFIC SYMPOSIUM REGION, ENTREPRENEURSHIP, DEVELOPMENT, Under the auspices of: REPUBLIC OF CROATIA MINISTRY OF SCIENCE AND EDUCATION, Osijek, June, 690-703.

Lukic, R., Vojteski Kljenak, D. and Andjelic, S. (2020 b ). ANALYZING FINANCIAL PERFORMANCES AND EFFICIENCY OF THE RETAIL FOOD IN SERBIA BY USING THE AHP TOPSIS METHOD. Economics of Agriculture, 67(1), 55-68.

Lukić, R. (2020c). Računovodstvo trgovinskih preduzeća. Beograd: Ekonomski fakultet.

Lukic, R. (2020d). ANALYSIS OF THE EFFICIENCY OF TRADE IN OIL DERIVATIVES IN SERBIA BY APPLYING THE FUZZY AHP-TOPSIS METHOD. Business Excellence and Management, 10 (3), 80-98.

Lukic, R., Vojteski Kljenak, D., Anđelic, S. and Gavilovic, M. (2021a). Application WASPAS method in the evaluation of efficiency of agricultural enterprises in Serbia. Economics of Agriculture , 68(2), 375-388.

Lukic. R. (2021b). ANALYSIS OF THE EFFICIENCY OF INSURANCE COMPANIES BY LINES OF INSURANCE IN SERBIA USING THE COCOSO METHOD. Tokovi osiguranja, 2, 24-38. DOI: 10.5937 / TokOsig2102009L

Lukić, R. (2021c). Analiza efikasnosti finansijskih institucija na bazi OCRA metode. Tehnika, 76(1), 103111. DOI: $10.5937 /$ tehnika2101103L

Lukic, R. (2021d). Application of MABAC Method in Evaluation of Sector Efficiency in Serbia. Review of International Comparative Management, 22(3), 400-417. DOI: 10.24818/RMCI.2021.3.400

Lukic, R. (2021e). APPLICATION OF THE EDAS METHOD IN THE EVALUATION OF BANK EFFICIENCY IN SERBIA. Bankarstvo, 50(2), 13-24. doi: 10.5937/bankarstvo2102064L

Milani, A. S., Shanian, A., \& El-Lahham, C. (2006). Using different ELECTRE methods in strategic planning in the presence of human behavioral resistance. Advances in decision sciences , 1-19.

Memariani, A., Amini, B. and Alinezhad, A. (2009). Sensitivity analysis of Simple Additive Weighting method (SAW): The results of change in the weight of one attribute on the 77 final ranking of alternatives. Journal of Industrial Engineering , 2 (4), 13-18. Retrieved from http://www.qjie.ir/?_ action $=$ articlelnfo \& article $=28$

Vural, D. \& Köse, E. (2020). Selection of Alternative Filling Material in The Bed Production with AHP and ELECTRE Methods. Journal of Applied Research on Industrial Engineering, 7 (2), 163-176.

Velasquez, M. and Hester, P. T. (2013). An analysis of multi-criteria decision making methods. International Journal of Operations Research , 10, 56-66.

Triantaphyllou, E., Shu, B., Sanchez, S. N., \& Ray, T. (1998). Multi-criteria decision making: an operations research approach. Encyclopedia of electrical and electronics engineering, 15 (175186.

Wu, M. C. (2019). Comparative study of ELECTRE methods with intuitionistic fuzzy sets applied on consumer decision making case. Eur. J. Eng. Res. Sci ., 4 (10), 103-110. 
Lukic, $\mathbf{R}$.

APPLICATION OF ELECTRE METHOD IN PERFORMANCE ANALYSIS OF FOOD RETAILERS IN SERBIA

Yeh, C. H. and Willis, R. J. (2001). A validation procedure for multicriteria analysis: application to the selection of scholarship students. Asia Pacific Managemenl Review, 6 (1), 39-52. 